\title{
Falling television related child injuries in Turkey: 10-year experience
}

\author{
Türkiye'de televizyon düşmesi nedeni ile gelişen çocuk yaralanmaları: \\ 10 yillik deneyim \\ Recep GÜLOĞLU, ${ }^{1}$ İnanç Şamil SARICI, ${ }^{1}$ Süleyman BADEMLER, ${ }^{1}$ Selman EMİRIKÇİ, ${ }^{1}$ \\ Halim İŞSEVER, ${ }^{2}$ Hakan YANAR, ${ }^{1}$ Cemalettin ERTEKİN ${ }^{1}$
}

\section{BACKGROUND}

We reviewed retrospectively TV-related injuries to determine the risk factors, type of injuries, and operative intervention(s) required in children injured by falling TVs.

\section{METHODS}

This was a retrospective descriptive study conducted on 42 pediatric patients who were admitted to Istanbul University, Istanbul Medical Faculty, Emergency Surgery Department. Case notes included all demographic and injury details, TV and TV-related furniture type, mechanism of injury, Pediatric Trauma Score (PTS), Pediatric Glasgow Coma Scale (PGCS), length of hospital stay, need for intensive care unit assessments, and management plans.

\section{RESULTS}

More than $65 \%$ of the children were aged 1 to 3 years. The injury rate was higher for boys $(66.7 \%)$ than girls $(33.3 \%)$. Of the 42 patients identified, 17 (40.5\%) sustained only head injuries, with almost half of these having a definite traumatic brain injury; $6(14.3 \%)$ had only thoracic injury, and $4(9.5 \%)$ had only limb injury. The PGCS ranged from 3 to 15 , with a mean of 7 . The PTS ranged from -6 to 12 , with a mean of 9 . Five children $(11.9 \%)$, all aged 2 years or younger, died in the hospital as a result of the TV-related injury, all sustaining head and thorax injuries, which are reflected in a significantly lower PTS and lower PGCS on admission compared with older children. TV falls on to children often occur because of unstable supports, with dressers and shelves being the most common. The most common mechanism of injury $(71.4 \%)$ among all age groups was fall/tipping of furniture. Pulling the furniture onto oneself $(19 \%)$ was the second most frequent mechanism of injury.

\section{CONCLUSION}

Injuries related to TV falls can lead to significant morbidity and mortality in children. As they are preventable injuries, restricted activity and improved supervision of children around the TV can potentially lead to fewer incidences.

Key Words: Children; furniture type; pediatric Glasgow coma scale; pediatric trauma score; television; injury.

\section{AMAÇ}

$\mathrm{Bu}$ çalışmada, üzerine televizyon (TV) düşmesi sebebiyle yaralanan çocukların risk faktörleri, yaralanma çeşitleri ve cerrahi girişimler geriye dönük olarak incelendi.

\section{GEREC VE YÖNTEM}

Bu çalışmaya İstanbul Üniversitesi, İstanbul Tıp Fakültesi, Travma ve Acil Cerrahi Birimine başvuran 42 çocuk hasta dahil edildi. Olguların tümünde demografik ve yaralanma detayları, televizyon tipleri, mobilya türü, yaralanmanın mekanizması, pediatrik travma skoru (PTS), pediatrik Glaskow koma skalası (PGKS), hastanede kalış süresi, yoğun bakım ünitesi değerlendirmesinin gerekliliği ve tedavi planları incelendi.

\section{BULGULAR}

Çocukların \%65'inden fazlası 1 ile 3 yaş arasında idi. Yaralanma erkeklerde $(\% 66,7)$, kızlara $(\% 33,3)$ oranla daha fazla idi. Kırk iki hastanın 17 'sinde $(\% 40,5)$ sadece kafa travması mevcuttu, bunların yaklaşık olarak yarısında travmatik beyin hasarı görüldü. Altı hastada sadece toraks travması $(\% 14,3)$ ve dört hastada ise $(\% 9,5)$ sadece ekstremite travması saptand1. Ortalama PGKS 7 (3-15) ve ortalama PTS 9 (-6 ve 12) idi. TV düşmesi sonucu beş çocuk hayatını kaybetti, bunların hepsi iki yaş ve altında idi ve hepsinde kafa ve toraks travması bulunmaktaydı. Bu çocukların başvuru anındaki PTS ve PGKS skorları daha büyük çocuklara oranla daha düşüktü. TV düşmesi sonucu yaralanmaların en sık nedeni uygun olmayan sabitleyicilerdir. Büfeler ve raflarda bu sorun daha siktır $(\% 71,4)$, en sık yaralanma mekanizmaları ise mobilyanın üzerine düşmesi veya çocuğun mobilyayı kendi üzerine doğru çekmesidir (\%19).

\section{SONUÇ}

Televizyon düşmeleri ile ilgili yaralanmalar çocuklarda ciddi morbidite ve mortaliteye yol açabilir. Bunlar önlenebilir yaralanmalardır. Çocukların televizyon etrafındaki hareketleri kısıtlanmalı ve çocuklar mutlaka iyi denetlenmelidir.

Anahtar Sözcükler: Çocuk; mobilya tipi; pediatrik Glaskow koma skalası; pediatrik travma skoru; televizyon; yaralanma.

\footnotetext{
Presented at the 8th Congress of National Trauma and Emergency Surgery (September 14-18, 2011, Antalya, Turkey).

Departments of ${ }^{1}$ General Surgery, Trauma and Emergency Surgery Service, ${ }^{2}$ Public Health, Istanbul University Istanbul Faculty of Medicine,
} Istanbul, Turkey.

8. Ulusal Travma ve Acil Cerrahi Kongresi'nde sunulmuştur (14-18 Eylül 2011, Antalya).

İstanbul Üniversitesi İstanbul Tıp Fakültesi, ${ }^{1}$ Genel Cerrahi Anabilim Dalı, Travma ve Acil Cerrahi Servisi, ${ }^{2}$ Halk Sağlığı Anabilim Dalı, İstanbul. 
Trauma is responsible for a significant number of childhood deaths, with a high percentage of injuries occurring within the home environment. ${ }^{[1,2]}$ Television (TV) falls are a significant cause of morbidity and mortality in pediatric patients, most frequently among those between 0 and 5 years of age, and tend to result in head, thoracic and extremity injuries. ${ }^{[3,4]}$ There are few studies documenting this relatively unknown problem in the pediatric literature. ${ }^{[5]}$ The rising number and nature of pediatric injuries secondary to falling TV sets correlate with the increasing number of home TVs sold per year. ${ }^{[3]}$

We reviewed retrospectively TV-related injuries to determine the risk factors, spectrum of injuries, and operative intervention(s) required in children injured by falling TVs. This article represents the first study to be conducted in Turkey about injuries among children due to falling TVs.

\section{MATERIALS AND METHODS}

This was a retrospective descriptive study conducted among 42 pediatric patients who were admitted to Istanbul University, Istanbul Medical Faculty, Emergency Surgery Department with a TV fall injury between January 2001 and December 2010. All children were under the age of 9 years. Information gathered from the registry and case notes included all demographic and injury details, TV types, furniture type, mechanism of injury, Pediatric Trauma Score (PTS), Pediatric Glasgow Coma Scale (PGCS), length of hospital stay, need for intensive care unit (ICU) assessments, and management plans. Analyses of injury and hospitalization data were performed on selected age groups, based on consideration of developmental skills that might be involved in this type of injury. The children were grouped as follows: $<1$ year, 1-3 years, and $\geq 3$ years. Patients underwent a physical examination, and complete blood count, biochemical analysis, abdominal X-ray, abdominal ultrasonography, and cranial, thoracic and abdominal computerized tomography $(\mathrm{CT})$ were performed. All patients were consulted with orthopedics, neurosurgery and pediatrics.

\section{Statistical Analysis}

The Statistical Package for the Social Sciences (SPSS) 16.0 (SPSS Inc, Chicago, IL) program was

Table 1. TV injuries according to gender and age groups

\begin{tabular}{lccccc}
\hline & \multicolumn{3}{c}{ Gender } & & Significance \\
\cline { 2 - 4 } Age groups & Male & Female & Total & & \\
\hline$<1$ year & 5 & & 5 & & $\mathrm{X}^{2}=4.51$ \\
1-3 years & 19 & 9 & 28 & & $\mathrm{p}=0.10$ \\
$\geq 3$ years & 4 & 5 & 9 & & \\
Total & 28 & 14 & 42 & \\
\hline
\end{tabular}

used for the statistical analysis. The results regarding continuous variables were given as the mean and standard deviation, while results regarding discrete data were given as frequency and percentage. According to gender and age, varying types and the results were compared with chi-square. Statistical significance was considered to be two-way and with a $\mathrm{p}$ value $<0.05$.

\section{RESULTS}

The patients who were injured by TV falls and admitted to our hospital ranged in age from 0 to 9 years, with a mean age of 2.1 years. More than $65 \%$ of the children were in the 1-3 years range, and the rate of injury was higher among boys (66.7\%) than girls $(33.3 \%)$ (Table 1). The majority of injuries sustained by children involved trauma to the head, thorax and abdomen and extremity fractures. Of the 42 patients identified, 17 (40.5\%) had sustained only head injuries, with almost half of these having a definite traumatic brain injury; $6(14.3 \%)$ had only thoracic injury, and $4(9.5 \%)$ had only limb injury. Three $(7.1 \%)$ patients had head and thoracic injury, and $2(4.8 \%)$ had head and limb injury (Table 2). The PGCS ranged from 3 to 15 , with a mean of 7 . The PTS ranged from -6 to 12 , with a mean of 9 . Five $(11.9 \%)$ children, all aged 2 years or younger, died in the hospital as a result of TV-related injury (Table 3), all sustaining head and thorax injuries, which are reflected in a significantly lower PTS and lower PGCS on admission compared with older children. The mean length of hospital stay was 2.3 days. Sixteen (38.1\%) patients were admitted to the ICU. The mean length of stay in the ICU was 16.2 days. Children aged 1-3 years were observed to have the longest overall hospital stay. Twelve (28.6\%) patients required surgery, and all of them were younger than 6 years. Five patients underwent neurosurgical procedures -2 had thoracic surgery and 3 had abdominal operations. Orthopedic stabilization was required in 5 patients aged 4-6 years. Plastic surgery was needed for 3 patients, all over 7 years of age. All TV-related injuries were sustained in the child's own home, with the exception of one that occurred at a relative's house. However, $95.2 \%$ of the events were not witnessed by a caregiver at the time of the incident. The caregiver was either the mother (32 patients), father ( 9 patients) or a relative (1 patient). The most common TV size was 22 inches (24 patients), but sizes ranged from 15.4 inches (10 patients) to 27 inches (8 patients).

The average height of the fall was 1.2 meters (range: 0.8 to 3 meters). A trend toward an increased number of liquid crystal display (LCD) TV-related injuries during the study period was observed, especially after 2004. TV falls occurred often because of unstable supports. The type of furniture was grouped into 6 categories (Fig. 1), with dressers and shelves being the most common. The mechanism of injury was 
Table 2. TV injuries according to age groups and injury area

\begin{tabular}{|c|c|c|c|c|c|c|c|}
\hline Age groups & Thorax & Extremity & Head + Thorax + Abdomen + Pelvis & Head & Abdomen & Total & Significance \\
\hline$<1$ year & 1 & 1 & - & 1 & 2 & 5 & $X^{2}=6.44$ \\
\hline $1-3$ years & 5 & 3 & 6 & 11 & 3 & 28 & $\mathrm{p}=0.59$ \\
\hline$\geq 3$ years & 1 & - & 2 & 5 & 1 & 9 & \\
\hline Total & 7 & 4 & 8 & 17 & 6 & 42 & \\
\hline
\end{tabular}

Table 3. Age groups and mortality

\begin{tabular}{lccccc}
\hline & \multicolumn{3}{c}{ Mortality } & & Significance \\
\cline { 2 - 4 } Age groups & Yes & No & Total & \\
\hline$<1$ year & 0 & 5 & 5 & & $\mathrm{X}^{2}=2.83$ \\
1-3 years & 5 & 23 & 28 & & $\mathrm{p}=0.10$ \\
$\geq 3$ years & 0 & 9 & 9 & & \\
Total & 5 & 37 & 42 & \\
\hline
\end{tabular}

grouped into 4 categories as: (1) falling/tipping over, (2) pulling onto self, (3) climbing furniture, and (4) unknown. The most common (71.4\%) mechanism of injury among all age groups was falling/tipping over of furniture, followed by pulling the furniture onto oneself $(19 \%)$.

\section{DISCUSSION}

Today, the TV has become an integral part of every household around which most family activity is centered. This popular electronic item is a relatively unknown in-home hazard, and a small number of previous studies have documented TV falls as a significant cause of morbidity and death in younger pediatric patients. ${ }^{[3-5]}$ Previous studies suggest that the incidence of these types of injuries may be on the rise. ${ }^{[4,6]}$ DiScala et al. ${ }^{[4]}$ reported 183 injured children from the National Pediatric Trauma Registry over a 10-year period, and Scheidler et al. ${ }^{[3]}$ reported 43 cases over 10 years from the Pennsylvania Trauma Outcome Study. The overall consensus is that, although most injuries are mild, the potential for serious harm exists, as re-

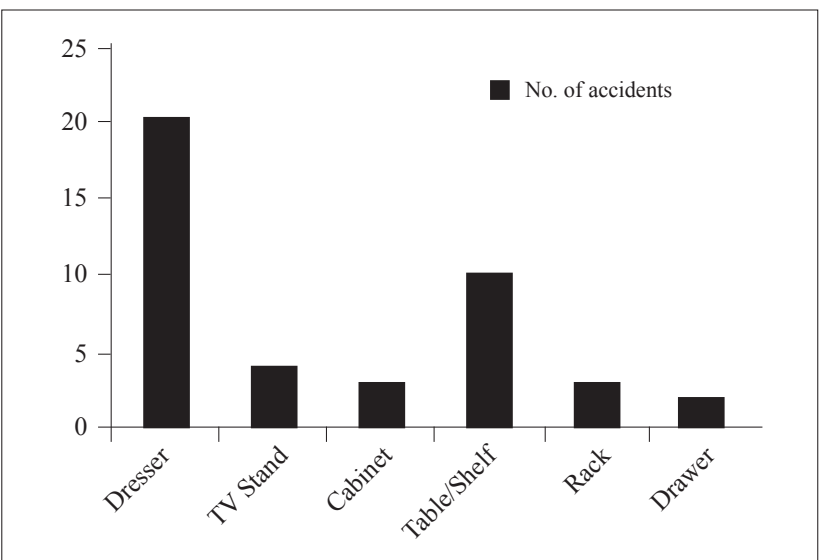

Fig. 1. Type of furniture as grouped into 6 categories. flected by the number of ICU admissions and deaths. ${ }^{[3-6]}$ In this study, a total of 42 pediatric injuries by TV fall occurred during the 10-year period, and the mortality rate was $11.9 \%(5 / 42)$.

In the previous literature, head injuries were the most common form of injury and cause of death in pediatric trauma patients. ${ }^{[3,4]}$ The results of this study are similar to previous reports of TV-related injuries being highest among children aged 1-3 years, with a higher proportion of head injuries. It is unlikely that children under 1 year of age can pull the TV onto themselves; it is more likely that the child bumps into the TV stand, causing the TV to fall onto the child. The first body part hit by the falling TV is likely to be the head due to the child's height in relation to the height of the stand. Moreover, toddlers sustained a high number of concomitant abdominal injuries. ${ }^{[7]}$ Thus, a thorough abdominal evaluation is required in a child injured by a fallen TV to identify occult injuries. In this study, the most commonly injured site was the head $(40.5 \%)$, but 3 patients $(7.1 \%)$ over the age of 3 years required an abdominal operation. Thus, an abdominal evaluation is needed for these kinds of injuries.

There are several possible explanations for the increase in TV fall-related injuries. Many studies have documented the rise in the number of TVs in recent years. ${ }^{[8,9]}$ Thus, the more TVs in a household, the greater the child's exposure to risk of injury due to TV fall. With the advent of flat-panel TVs (FPTs) (such as LCD and plasma), these TVs are lighter and thinner, and are therefore thought to reduce the risk of tipovers significantly. ${ }^{[4]}$ On the other hand, the slim design and lighter weight of the FPTs may allow children to grasp and move the TV, making it easier to knock over. Thus, whether the increase in FPTs continues or decreases, TV fall-related injury rates remain unclear. In our study, there was an increased number of LCD TV-related injuries, especially after 2004. We think that this was due to the positioning of LCD TVs on unstable supports. One of the benefits of FPTs is that their flat shape allows them to be fastened to walls, out of the reach of children, or on a stable surface, which decreases the chance of tipping.

Our data show that the majority of children who sustained injuries from falling TVs were 3 years of age. In our study, the mechanisms of 'falling/tipping 
over' and 'pulling the furniture onto self' accounted for $100 \%$ of deaths. The high incidence of injury in this age group is likely related to immature coordination. ${ }^{[10]}$ On the other hand, toddlers have the motor skills to climb nearby objects and explore their environment. However, they may not possess the reflexive ability to avoid falling objects or the cognitive skills to deduce ensuing danger. TVs may be placed on furniture that was not designed to hold such weight, such as dressers and shelving units. ${ }^{[11]}$ As a result, TVs are even more prone to tipping and falling when pulled or knocked by a child, and can bring their supporting furniture down as well. In our study, a variety of supportive structures were involved in the accidents, but dressers were the most common. Lack of parenteral knowledge of this injury mechanism may contribute to its incidence. ${ }^{[12]}$

In conclusion, we can assume that almost all Turkish children are exposed to TV sets in their home environment. ${ }^{[13]}$ TV fall-related injuries can lead to significant morbidity and mortality in children. As they are preventable injuries, restricted activity and improved supervision of children around the TV can potentially lead to fewer incidences.

\section{REFERENCES}

1. Brenner RA, Overpeck MD, Trumble AC, DerSimonian R, Berendes H. Deaths attributable to injuries in infants, United States, 1983-1991. Pediatrics 1999;103:968-74.

2. Marganitt B, MacKenzie EJ, Deshpande JK, Ramzy AI, Haller JA Jr. Hospitalizations for traumatic injuries among children in Maryland: trends in incidence and severity: 1979 through 1988. Pediatrics 1992;89:608-13.

3. Scheidler MG, Shultz BL, Schall L, Vyas A, Barksdale EM Jr. Falling televisions: The hidden danger for children. J Pediatr Surg 2002;37:572-5.

4. DiScala C, Barthel M, Sege R. Outcomes from television sets toppling onto toddlers. Arch Pediatr Adolesc Med 2001;155:145-8.

5. Bernard PA, Johnston C, Curtis SE, King WD. Toppled television sets cause significant pediatric morbidity and mortality. Pediatrics 1998;102:E32.

6. Jea A, Ragheb J, Morrison G. Television tipovers as a significant source of pediatric head injury. Pediatr Neurosurg 2003;38:191-4.

7. Ota FS, Maxson RT, Okada PJ. Childhood injuries caused by falling televisions. Acad Emerg Med 2006;13:700-3.

8. Taras HL, Sallis JF, Nader PR, Nelson J. Children's television-viewing habits and the family environment. Am J Dis Child 1990;144:357-9.

9. Tonge BJ. The impact of television on children and clinical practice. Aust N Z J Psychiatry 1990;24:552-60.

10. Rutkoski JD, Sippey M, Gaines BA. Traumatic television tip-overs in the pediatric patient population. J Surg Res 2011;166:199-204.

11. Gottesman BL, McKenzie LB, Conner KA, Smith GA. Injuries From furniture tip-overs among children and adolescents in the United States, 1990-2007. Clin Pediatr (Phila) 2009; $48: 851-8$.

12. Murray KJ, Griffin R, Rue LW 3rd, McGwin G Jr. Recent trends in television tip over-related injuries among children aged 0-9 years. Inj Prev 2009;15:240-3.

13. Özkaya C, Vatandaş C, Aydın M, Tekin M, Can B, Arabacı C ve ark. Türkiye'de aile (Ailenin yapısal özellikleri, işlevleri ve değişimi). İstanbul: SEKAM Yayınları; 2011. s. 217-23. 